Metabolic Products of Microorganismen. 270

\section{The Structures of the Exfoliamycins}

\section{Corinna Volkmann and Axel ZeecK*}

Institut für Organische Chemie, Universität Göttingen, Tammannstr. 2, D-37077 Göttingen, Germany

\section{Olivier Potterat ${ }^{\dagger \dagger}$ and Hans ZÄHNER}

Biologisches Institut, LB Mikrobiologie/Antibiotika, Universität Tübingen, D-72076 Tübingen, Germany

Frank-Michael Bohnen and Regine Herbst-Irmer

Institut für Anorganische Chemie, Universität Göttingen, Tammannstr. 4, 37077 Göttingen, Germany

(Received for publication December 8, 1994)

Recently, we have reported the isolation and characterization of the exfoliamycins $(\mathbf{1} \sim \mathbf{3})$, new antibacterial naphthoquinone C-glycosides from Streptomyces exfoliatus ${ }^{2}$. The connectivity within the unusual pentosyl moiety could not be proved unambigiously, because of signal overlapping in the ${ }^{1} \mathrm{H}$ NMR spectra. The situation took a turn to the better by using tetra- $O$-acetyl-anhydroexfoliamycin (4) but no stereochemical details could be given for the tetrahydrofuranyl residue. In this paper we wish to report the X-ray structure analysis of $\mathbf{4}$ and detailed NOE experiments in case of 2. Both investigations lead to the structures of $1 \sim 3$ including their relative stereochemistry ${ }^{3}$.

Crystals of 4 (orange needles, $\mathrm{C}_{30} \mathrm{H}_{32} \mathrm{O}_{12}$, MW 584.6) were obtained by liquid-liquid diffusion from a dichloromethane-hexane solvent system at $8^{\circ} \mathrm{C}$. The size of the X-ray specimen was about $0.5 \times 0.4 \times 0.3 \mathrm{~mm}$. Data were collected on a Siemens-Stoe-AED-diffractometer with graphite monochromated $\mathrm{MoK}_{\alpha}$ radiation $(\lambda=$ $71.073 \mathrm{pm})$. The crystal data are as follows: Orthorhombic, space group $\mathrm{P} 2{ }_{1} 2_{1} 2_{1}$. Cell dimensions, $\mathrm{a}=531.9$ (1), $\mathrm{b}=1861.6$ (2), $\mathrm{c}=2876.8$ (3) $\mathrm{pm}, \mathrm{V}=2.8486$ (7) $\mathrm{nm}^{3}$, $\mathrm{Z}=4, \mathrm{D}_{\text {cale }}=1.363 \mathrm{Mg} / \mathrm{m}^{3}, \mu=0.106 \mathrm{~mm}^{-1}$, data collec-

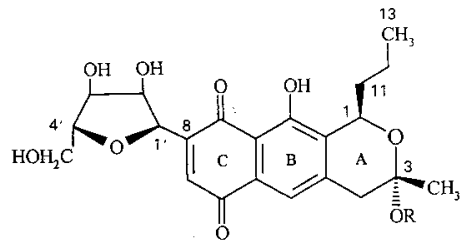

$1 \mathrm{R}=\mathrm{H}$ (exfoliamycin)

$2 \mathrm{R}=\mathrm{CH}_{3}$ (3-O-methylexfoliamycin) tion with profile fitting method ${ }^{4)}$ at $-120^{\circ} \mathrm{C}, 2 \theta$ range $=8$ to $45^{\circ}, 5451$ reflections measured, all 3750 unique reflections used for refinement. The crystal structure was solved by direct methods (SHELXS-90 $0^{5}$ ) and the 385 parameters were refined by full matrix least squares method on $F^{2}$ (SHELXL-93 ${ }^{6)}$ ). Non hydrogen atoms were refined anisotropically. A riding model starting from calculated positions was employed for the hydrogen atoms. The absolute structure could not be determined reliably. $\mathrm{R} 1=0.0451$ for $\mathrm{I}>2 \sigma(\mathrm{I})$ and $\mathrm{wR} 2=0.1014$ for all data, $\mathrm{w}^{-1}=\sigma^{2}\left(\mathrm{~F}_{\mathrm{o}}^{2}\right)+(0.048 \mathrm{P})^{2}+0.1449 \mathrm{P}$ with $\mathrm{P}=$ $\left(\mathrm{F}_{\mathrm{o}}^{2}+2 \mathrm{~F}_{\mathrm{c}}^{2}\right) / 3$, max. residual density $158 \mathrm{e}^{-} \mathrm{nm}^{-3}(\mathrm{R} 1=$ $\left.\Sigma\left(\left|\mathrm{F}_{\mathrm{o}}\right|-\left|\mathrm{F}_{\mathrm{c}}\right|\right) / \Sigma\left|\mathrm{F}_{\mathrm{o}}\right|, \quad \mathrm{wR} 2=\left(\Sigma \mathrm{w}\left(\mathrm{F}_{\mathrm{o}}^{2}-\mathrm{F}_{\mathrm{c}}^{2}\right)^{2} / \Sigma \mathrm{wF}_{\mathrm{o}}^{4}\right)^{1 / 2}\right)$. Further details of the crystal structure investigation are available on request from the Fachinformationszentrum Karlsruhe, Gesellschaft für wissenschaftlich technische Information mbH, D-76344 Eggenstein-Leopoldshafen (Germany), on quoting the depository number CSD401386 , the names of the authors and the journal citation.

The results of the X-ray analysis of $\mathbf{4}$ are given in Fig. $1^{7)}$. The six-membered ring $A$ is puckered at $\mathrm{C}-1$ and $\mathrm{O}-2$. The plane of the tetrahydrofuranyl residue in the envelope conformation $\left(\mathrm{C}-2^{\prime} \sim \mathrm{C}-1^{\prime} \sim \mathrm{O}-1^{\prime} \sim \mathrm{C}-4^{\prime}\right)$ shows an angle of $66.0^{\circ}$ with the plane of the essentially flat naphthoquinone portion (ring B and C). The absolute stereochemistry could not be determined but the relative stereochemistry of the stereocenters at C-1 and in the

Fig. 1. Crystal structure of tetra- $O$-acetyl-anhydroexfoliamycin (4).

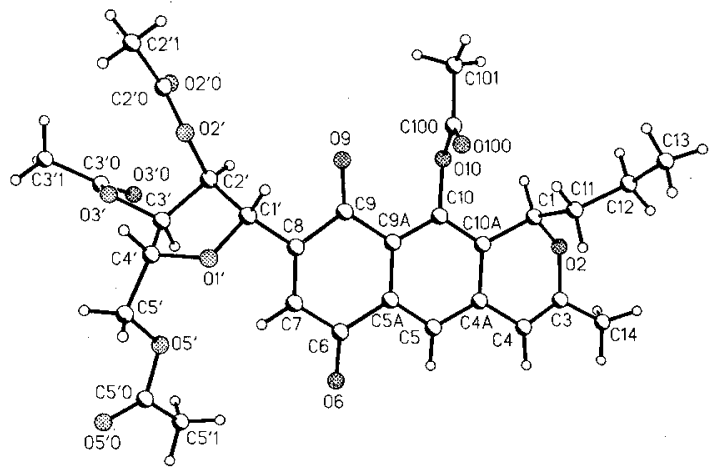

The absolute configuration has not been proved.

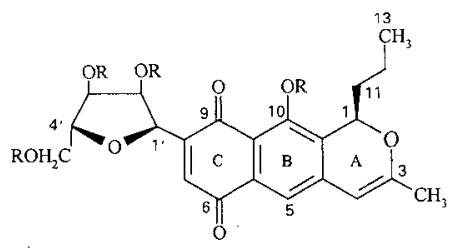

$3 \quad \mathrm{R}=\mathrm{H}$ (anhydroexfoliamycin)

$4 \mathrm{R}=\mathrm{Ac}$

$\dagger$ See ref. 1.

${ }^{\dagger \dagger}$ Present address: Institut de Pharmacognosie et Phytochimie, B.E.P. Universite de Lausanne, CH-1015 Lausanne-Dorgny. 
Fig. 2. NOESY analysis $\left(300 \mathrm{MHz}\right.$, acetone- $\left.d_{6}\right)$ of $3-O-$ methylexfoliamycin (2).

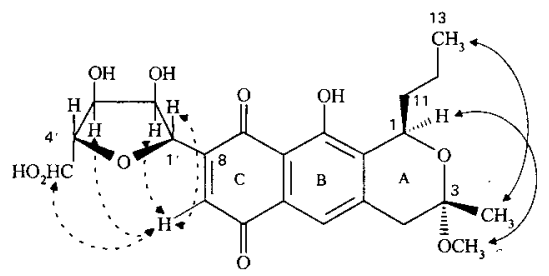

tetrahydrofuranyl residue were obtained. The latter is in accordance with a C-glycosidically bound ribose. Assuming that the producing strain has accepted D-ribose as precursor, the absolute configuration could be derived as given in the formulae $1 \sim 4$.

The relative stereochemistry of ring $A$ of 2 could be determined by a NOESY experiment ${ }^{8)}$. A significant NOE (nuclear Overhauser enhancement) effect between $13-\mathrm{H}_{3}$ in the propyl chain and $3-\mathrm{CH}_{3}$ as well as between $3-\mathrm{OCH}_{3}$ and $1-\mathrm{H}$ caused us to assume that the paired groups are located on the same side of the ring plane (Fig. 2). Far off four striking NOE effects between 7-H and $\mathbf{1}^{\prime}-\mathrm{H}, 2^{\prime}-\mathrm{H}, 3^{\prime}-\mathrm{H}$ and $5^{\prime}-\mathrm{H}_{2}$ confirmed the sugar ribose, which was likewise analyzed by $\mathrm{X}$-ray methods.

\section{References}

1) Potterat, O.; H. Zähner, J. W. Metzler \& S. Freund: Metabolic products of microorganisms. 269. 5-Phenylpentadienoic-acid derivatives from Streptomyces sp., Helv. Chim. Acta 77: 569 574, 1994

2) Potterat, O.; H. Zähner, C. Volkmann \& A. Zeeck: Exfoliamycin and related metabolites, new naphtoquinone antibiotics from Streptomyces exfoliatus. J. Antibiotics 46: 346 349, 1993

3) Volkmann, C.: Strukturaufklärung neuer Naphthochinon-Antibiotika aus Streptomyceten und Synthese neuer Pyron-Derivate in Anlehnung an biologisch aktive Naturstoffe. Ph.D. Thesis, University of Göttingen, Cuvillier Verlag Göttingen, 1994

4) ClegG, W.: Faster data collection without loss of precision. An extension of the learnt profile method. Acta Crystallogr. (A) 37: 22 28, 1981

5) Sheldrick., G. M.: Phase annealing in SHELX-90. Direct methods for larger structures. Acta Crystallogr. (A) 46: 467 473, 1990

6) SHELdRICK, G. M.: SHELXL-93, Universität Göttingen 1993

7) SHELDRICK, G. M.: XP Molecular Graphics, Siemens A. X. I., Madison 1988

8) Kessler, H.; M. Gehrke \& C. Griesinger: Twodimensional NMR spectroscopy, principles and survey of the experiments. Angew. Chemie, Int. Ed. Engl. 27: $460 \sim 507,1988$ 